\title{
The Relationship between Parental Involvement and the Students' Achievement at the Eighth Grade Students of MTs Negeri 1 Makassar
}

\author{
Sitti Maryam Hamid \\ maryamhamid@unismuh.ac.id
}

\author{
Muhammadiyah University of Makassar, Indonesia
}

\begin{abstract}
The objective of this research were to analyze: (1) parental involvement in the students ${ }^{\text {ee }}$ achievement at the Eighth Grade Students of MTsNegeri 1 Makassar. (2) the relationship between parental involvement and students ${ }^{\text {ee }}$ achievement at the eighth grade students of MTsNegeri 1 Makassar.The researcher used descriptive correlation research. There were two variables in this research, namely parental involvement (variable X) and the students ${ }^{\text {ee }}$ English achievement (variable Y). The technique of collecting data used questionnaire and documentation. The questionnaire consisted of 24 items. The sample of this research was 42 students. The result of the research showed that forms of parental involvement are found at the eighth grade of MTsNegeri 1 Makassar, the mean score of parenting was 3.20, communicating was 2.76 , volunteering was 2.43 , learning at home was 2.49 , decision making was 2.78 , collaborating with community was 2.53 , and the total of the mean score was 16.19. It means that parental involvement of the eighth grade students of MTsNegeri 1 Makassar is low level. Based on the result of the research, it showed that there was a relationship between parental involvement and students ${ }^{\text {ee }}$ English achievement at the eighth grade students of MTsNegeri 1 Makassar in Academic Year of 2018/2019 because $\mathrm{r}=$ 0,125 .
\end{abstract}

Key Words: Parental Involvement, Students' English Achievement

\section{INTRODUCTION}

Education is imperative for growth and success of all the children in the world. Every students in a different manner, and has different factors that influence her or her learning. Many factors that affact students and their development as learners are enviromental factors. List of the most debated factors as well as the degradation which are the factors that influence learning. Family is the biggest factor that determines the level of success students will get during their education. Davis and Sexton (2009) stated that families succeeded in making model values, beliefs, and needs needed by students to succeed.

There are many different aspects of life that can affect a student's ability to learn both inside and outside of school. Ethnicity and race, socioeconomic status, religion, and parental participation in education have all been considered as factors that students agree to achieve academic success, or struggle throughout their educational careers. In particular, supporting parents is an increase where parents support their role as parents and to encourage optimal child development. This is usually a matter of the amount included in child-oriented education with academic achievement. 


\section{LITERATURE REVIEW}

\section{Previous Related Findings}

Karsidiet.al. (2013: 1) Parent Assistance in the Social School Committee to Improve Achievement Students have three: more parents agree to provide material, such as school fees and books; Most parents have a misunderstanding about school that must be responsible for the education of their children; busy parents avoid the difficulties of learning their children. To create social capital for their children, parents need to be active in the learning process, working with school teachers, and involved in planning social activities.

Pomerantset.al. (2007:3) Finding parental motivation to improve student achievement encourages motivation and supports students in school. The reaserch on parental involvement states the positive impact it had on student achievement outcomes; the impact was seen in the improvement of presence, behaviour,grades and efforts in completing homework.

Research on the relationship between parents and the success of students in schools has been saved by Edmonds and Walberg (1995: 49). Those who report about parents can have positive results on school processes and outcomes. Some researchers completed the effects of parental participation on student motivation and supporting schools.

The similarity of previous researcher with this research is parental involvement and students achievement. Nevertheless, the differences between this research and previous research as follows: first, Karsidiet.al's research tend to material aspects, such as tuition and books. Second, .Pomerantset.al ${ }^{\text {ee }}$ research focused on students ${ }^{\text {ee }}$ presence, behaviour, grades and effort in completing homework. Third, Edmonds and Walberg refer to motivation and school engagement. Whereas, this research revealed to sixparental involvement namely parenting, communicating, volunteering, learning at home, decision making, and collaborating with community. In addition, it only concern on the students ${ }^{\text {ee }}$ English achievement.

\section{Some Pertinent Ideas}

\section{Understanding Attention and Parental Involvement}

\section{Attention}

Richards (2004 : 282) states that attention may be definedas the selective enhancement of some behavior at the expense of otherbehavior. Attention is a common way how to move from associating soulwith materials in the field of behavior, with other version attention can beinterpreted two kinds, namely: a). Attention is drawn to something mentalstrength objects, b). Attention is the use of awareness to accompany anactivity.

Understanding the parents in terms of the language contains several meanings, sometimes mean people who are old, father's mother, older people, people who 
are considered old. Parents sometimes means leader / they are responsible for the survival of all matters among members of the leads in the institutions, agencies, unity, or official organizations such as government agencies, military and nondepartmental agencies, parents who referred the author is more widely used or emphasis on coaching and developing a sense of responsibility, professional and social relationships, in addition to acting as a protector against subordinates.

2. Parental Involvement

Desforges and Alberto (2003) state that parents are people who like to help other people in a good home, help with work at home, talk to teachers, talk about how to manage schools, to take part in managing school.It is relatively easy to describe what parents do in the name of involvement.

It is much more difficult to determine whether these activities are more different from school results, more important because school outcomes are demanded by many factors. In the same source, Desforges and Alberto said that many contemporary studies of parents in the US were drawn from the work of Joyce Epstein. Epstein has compiled a typology of the form of parent meetings. This framework is not based on empirical evidence from the names that support their children. Waiting, discussing general things that parents can do or do.

In "Shows to show how this helps teachers teach and learn children", it was agreed that Epstein (1997) of Johns Hopkins University had developed supporting work to support six types of parents. This framework helps educators in developing school and family partnership programs. "There are many reasons for developing schools, families, and community partnerships," he wrote. "The main reason is to offer a partnership to help all young sisters who succeed in school and in the next life." Epstein's framework agreed and a list of examples was collected in more meetings. Parents, and teachers.Six types of parents ${ }^{\text {ee }}$ involvement which contribute to the increase of educational quality at school:

\section{a. Parenting}

Parenting is a process of encouraging and supporting children's physical, emotional, social, financial and intellectual development from infancy to adulthood. Parenting children agrees on aspects of raising children apart from biological relationships.

\section{b. Communicating}

Design effective forms of school-to-home and home-to-school communication about school programs and children's progress. Today, through the so-called decentralized education system in Indonesia, it optimizes the role of parents. Parent participation depends on schools which require them in every aspect, not only in providing adequate infrastructure, because parents, as well as large groups, must become school partners. 


\section{c. Volunteering}

Volunteering is generally considered an altruistic activity and is intended to promote goodness or improve the quality of human life. Instead, this can result in feelings of self-respect and respect. There are no financial benefits involved for individuals. Volunteers can have positive benefits for volunteers and also the people or communities served.

\section{d. Learning at Home}

Give information and ideas to the family about how to help students at home with homework and activities, decisions, and planning related to other curricula. Lawson (2011: 2) also found that social networks and parent associations can overcome student problems. For example, it is important for parents to take part in the compilation of their children doing homework. Another way to learn about the emotional process and emotional state of their children.Kunar (2012:2) also asked for help from parents at home to have a positive and significant influence on the performance of children in school. Children will achieve better results in the parents' schools they produce more.

\section{e. Decision Making}

In psychology, making decisions is a number of alternatives. Every decision making process produces an end that may not be a quick action. Decision makers Decision making can be used as a problem solving with a solution that is considered satisfactory. Therefore, this is a process that can be more or less rational or tacit knowledge.

\section{f. Collaborating with Community}

Parents and school leaders must work with environmental associations, government agencies, businesses, and universities to strengthen schools. This collaboration must provide resources for students, school staff, and families and build a family-friendly community.Study after study identified the importance of parental involvement in student success in school. Some studies illustrate the presence of several factors which effectively increase the involvement of parents. The economic condition often is decisive level of support from parents. Quality is very welcome parental involvement in the classroom as a problem-solving team and as equal partners in the educational process .

Karsidi, et al (2013:1) states that the quality of education is influenced not only by the learning-teaching process and the infrastructure at schools, but also by the active participation of families. The father of education in Indonesia, $\mathrm{Ki}$ HadjarDewantara, is not well integrated. This implies parents and the community must contribute to the education process at school. Active participation of indicators is good school management. In other words, school management must help parents in their daily activities. 


\section{Role of cognitive aspect on Students 'e Success}

ACT $(2007: 2)$ explains that the key underlying constructs associated with success are: cognitive development, as measured by academic learning and achievement. We believe that this construct is very important for success because each reflects mastery of subject matter, general work attitudes, and effective career decision making. ACT (2007: 3) Some general attitudes and behaviors can help. Likewise, postsecondary and work-based choices are appropriate that match the interests and values of advocacy for assistance to support and continuous satisfaction.

\section{Forms of Attention Parents}

\section{How the Parents Educate}

The way parents educate a large influence on the motivation to learn their children. Family is very important container between the individual and the group, and is the first social group in which children become its member. And of course, the first is also a place to hold socialization of children's lives. Mother, father and siblings as well as other families are the first ones in which children first contact and also to teach the children that as he lives with others. Until children enter school, they were spending all their time in the family unit.

However, evidence of announcements about parents is not only important for school students, but also for subsequent academic approval (Catsambis, 2001).

To achieve a good education in the family, it is very necessary relationship between family members is the most important among parents with children in addition to the relationship with his child or the family members, the others were also influence children's learning. The form of the relationship such as whether the relationship was full of compassion and understanding or aversion, an attitude that is too hard, or indifferent attitude etc. The relation between these families of closely related to the way parents educate showed poor relation. Such relationships will lead to the development of children, stunted learning, distracted even can cause psychological problems others.

\section{Home Atmosphere}

The atmosphere of the house is intended as situations or events that often occur in families where children are and learn. Home atmosphere rowdy or boisterous and chaotic will not give peace to the children in the study. The atmosphere may occur in a large family which is always a lot of occupants. The tense atmosphere of the house, grab and often bicker quarrel between family members or with another family that causes the child tired of staying at home, like out of the house as a result of learning chaotic. In families broken home often found a boy who lost exemplary. Parents expect their children as an example, but there are still a small proportion of parents have not been able to demonstrate attitudes and behaviors. Finally disappointed children against parents, children feel restless and agitated, the child does not like living in home. Quietness and tranquility is the steps for children. So the atmosphere greatly influences the development of children's home, where the parents as educators in the family must be proficient in creating a conducive atmosphere of the house. 


\section{Economic Circumstances}

onomic problems related to the development of children who are learning for their basic needs, such as food, clothing, health protection and others, also require learning facilities such as classrooms, tables, chairs, lamps, stationery, books and others. Learning facilities that can only be completed if the family stays.

If children live in poor families, children lack basic needs are met, the health consequences of troubled children, so that children's learning is also disrupted, another result is a child always caused a wave of sadness, so that children feel inferior with another friend. This would disrupt children's learning, the child may even have to learn to make a living as a family helper even though the child is not the time to work, and it will also interfere with the child's learning. Although there is no doubt about the possibility of underprivileged children and families has always suffered from a weak economy, it is a state that is so a whip for him to study harder and finally a huge success.

\section{Function and Role of Family Education}

\section{First Experience of Childhood}

Childhood education period is also called hadanah time; this time for children ages 0-7 years. While next time period dhom is for children aged 7 years to adult. Experience in the domestic environment is the foundation stone in the growth and development of religion in every child. Family or household is first and foremost a place for children to acquire the mental development and formation of personality then added and perfected at school. This is in line with the opinion of John Lock, in theory Tabularasa that children like a clean white sheet of paper, what we scratched then that's the result.

Education in the family many children experience in the development of the state, especially the elderly in everyday life has a huge influence in the development of the child's personality. The facts demonstrate that the life of a child at the time it really depends on the parents. Parents are a child cleaves naturally. Therefore, parents are obliged to provide education to their children and foremost let the relationship of parents with children is natural and natural.

2. Assuring Child Emotional Lives

The atmosphere in the family is an atmosphere filled with love and sympathy is reasonable, the atmosphere is serene atmosphere of trust. For that through education of the family, emotional life or the need of affection can be catered for; this is due to a blood relationship between educators with children.

3. Instilling Basic Moral Education to Children

In the family environment is also a major planting moral grounds for children, which is usually reflected in the attitudes and behavior of parents as role models that can be replicated child. In this connection Ki Hajar Dewantara said that: "The love, united in a sense of feeling and mood, which is generally very useful for the ongoing education, especially moral education, there exists in the family life are strong and pure, so that there can be no center education-center with her ". Behavior, how to act and speak parents will become a reference that always 
imitated by children. This exemplary provide positive identification of symptoms, equating yourself with people who imitated, and it is important in the context of the formation of personality.

4. Providing Basic Social Education

Family life is a very important base in laying the foundations of the social education of children. Because basically the family is a social institution that is a minimum official consisting of father, mother and child. The development of the seeds of social awareness in children can be nurtured as early as possible, especially through family life full of mutual help, mutual assistance in the family, relatives or neighbors to help the sick, jointly maintain order, peace, cleanliness, and harmony in all things.

\section{Implementation Religious Basics}

The family as an educational institution first and foremost, in addition to a very decisive in instilling moral grounds, but not least is a major role in the process of internalization and information religious values into children's personalities. Coaching acts of worship in children, also starting from family. A child, exciting activities for her is that it contains aspects of movement, while the notion of religion was not understand. Because abstract religious teachings are not attractive its attention. Children like prayers imitate their parents.

\section{English Achievement}

English achievement is learners ${ }^{\text {ee }}$ ability to use the target language (English). It means the students have achieved the skill and knowledge in using target language- English. According to Scott Thornburry, English achievement is what learners have learned about target language - English, over a week, month, term or entire course.

Moreover, English achievement is how much of a foreign language (English) a student knows. Students have to struggle through a course or a learning experience of some sort to achieve a certain amount of control of the language. Besides those definitions, Theodore Huebener says that English achievement is the skills and the knowledge the pupils have acquired in each of the various phases of the language learning. Some definitions about the English achievement, the writer takes a conclusion that English achievement is the studentes ability, skill, and knowledge in English which they have acquired or learned in particular time.

\section{METHOD}

\section{Design and Sample}

The researcher utilized the quantitative research design approach.In particular, descriptive correlational research design was used to evaluate the relationship between parents and academic achievement of class 1 students in MTs Negeri.The 
researcher used purposive sampling technique. The total number sample was 42 students.

\section{Instrument and Procedures}

The instruments used in this research were questionnarie and documentation. First, questionnaire is a list of questions circulated and given to others in this case the respondent to be filled as desired researchers. In this questionnaire given to students at eighth grade of MTs Negeri 1 Makassar In this case:

- If you choose answer A scores $=4$

- If you choose answer B scores $=3$

- If you choose answer $\mathrm{C}$ scores $=2$

- If you choose answer $\mathrm{C}$ scores $=$

1 b. Documentation

Documentation is a technique used to collect data taken directly tothe location of the study by recording directly archives required by aresearcher, because the existence of this document is very easy to copy thedata researchers who will serve as the discussion in this study. In this casethe data taken are sourced from students at eighth grade of MTs Negeri 1 Makassar.

\section{Data Collection}

The data were gathered through Questionnaire and Documentation. Theresearcher used Questionnaire for the influence of parents to the students ${ }^{\text {ee }}$ successin school. Then, documentation section hed held after the data from collecting allof questionnaire. The questions will be directed to the students in the classroom.

\section{Data Analysis}

To find the relation between the students ${ }^{\text {ee }}$ success in school and parental involvement or there is a significant correlation between them, the researcher uses Data Nominal Spearman rho (SPSS). Spearman Correlation Coefficient is also referred to as Spearman Rank Correlation or Spearman's rho. It is typically denoted either with the Greek letter rho $(\rho)$, or rs. It is one of the few cases where a Greek letter denotes a value of a sample and not the characteristic of the general population. Like all correlation coefficients, Spearman's rho measures the strength of association of two variables. Thus, the Spearman Correlation Coefficient is close to the Bivariate Pearson Correlation Coefficient, Biserial Point Correlation, and Canonical Correlation. 
To classify the students ${ }^{\text {ee }}$ score, there were seven classifications which were used as follow:

\begin{tabular}{|c|c|c|}
\hline NO & Interval Score & Classification \\
\hline 1 & $96-100$ & Excellent \\
\hline 2 & $86-95$ & Very Good \\
\hline 3 & $76-85$ & Good \\
\hline 4 & $66-75$ & Fairly Good \\
\hline 5 & $56-65$ & Fair \\
\hline 6 & $36-55$ & Poor \\
\hline 7 & $0-35$ & Very Poor \\
\hline
\end{tabular}

(Depdikbud, 1986:6)

As the study used null and alternative hypothesis, the researcher firstly determine the level of probability at a $a=0.05$ and the degree of freedom (df). It means that if the probability is large than 0.05 ( $p>0.05)$, the alternative hypothesis are accept and reject the null hypothesis if any. The alternative way of decision making is comparing the count $r$ (correlation coefficient) with the Pearson $r$ table. If the $r$ is large than $r$-table, the alternative hypothesis are accept and reject the null hypothesis. The analysis result is than comparing to the index correlation table as follow:

\begin{tabular}{|c|c|}
\hline Coefficient Correlation & Level of Correlation \\
\hline $0.800-1.000$ & Very Strong \\
\hline $0.600-0.799$ & Strong \\
\hline $0.400-0.599$ & Fairly Strong \\
\hline $0.200-0.399$ & Weak \\
\hline $0.000-0.199$ & Very Weak \\
\hline \multicolumn{2}{|c|}{ (Sudjono,2014:214) } \\
\hline
\end{tabular}

\section{FINDINGS AND DISCUSSION}

\section{Findings}

On this section, the researcher presents the data of the parentalinvolvement in the students se success, and the relationship of parental involvementand students ${ }^{\text {ee }}$ success.

1. Parental Involvement in the Studentse Success

This part describes the level of parental involvement. To gather data,the researcher used questionnaire given to the students in the Eighth GradeStudents of MTs in Galesong Kabupaten Takalar to be delivered to theirparents. The score of questionnaire were listed by summing up the scores of parents" answer. To make easy in scoring the questionnaire, the researchermade measuring rod as in the previous chapter. Parental involvement wasdevided into five, namely: mean scores of parental involvement, the categoryof the role of parents at the eighth grade students, frequency of parentalinvolvement in the 
students" success, mean scores of students"e englishachievement and the category of students" achievement. The data can be seenclearly in table below:

Table. 1 Mean Score of Parental Involvement

\begin{tabular}{|c|c|c|}
\hline No. & Characteristic & Mean Score \\
\hline 1 & Parenting & 3.20 \\
\hline 2 & Communicating & 2.76 \\
\hline 3 & Volunteering & 2.43 \\
\hline 4 & Learning at Home & 2.49 \\
\hline 5 & Decision Making & 2.78 \\
\hline 6 & Collaborating with Community & 2.53 \\
\hline \multicolumn{2}{|c|}{ Total } & 16.19 \\
\hline
\end{tabular}

Based on the result of the data above, the next step is making the category ofthe role of parents. There is as follows.

Table 2. The Category of The Role of Parents at the Eighth Grade Students

\begin{tabular}{|c|c|}
\hline Interval & Category \\
\hline $0-25$ & Low \\
\hline
\end{tabular}

It is known that mean score is 16.19. It means thatparental involvement of the Eighth Grade Students of MTs Negeri 1 Makassar is low category. The frequency of parental involvement in the students ${ }^{\text {ee }}$ success can bepresented as followed:

Table 3. Frequency of Parental Involvement in the Students' Success

\begin{tabular}{|c|r|c|c|c|}
\hline Number of & \multicolumn{4}{|c|}{ Questionnaire } \\
\cline { 2 - 5 } Students & Always & Often & Sometimes & Seldom \\
\hline 42 & 12.29 & 11.86 & 6.96 & 10.87 \\
\hline
\end{tabular}

Table above shows that the parents ${ }^{\text {ee }}$ answers are always (12.29), often (11.88), sometimes (6.96), and seldom (10.87). It means the highestlevel of questionnaire is 12.29 and the lowest is 6.96 .

Table 4. Mean Scores of Students' English Achievement

\begin{tabular}{|c|c|}
\hline Number of the Students & Mean Score of English Achievement \\
\hline 42 & 75.86 \\
\hline
\end{tabular}

The table above states that the mean score of English achievement is 75.86. Based on the result of the data above, the next step is making the category ofstudents ${ }^{\text {ee }}$ achievement. There is as follows:

Table 5. The Category of Students' Achievement

\begin{tabular}{|c|c|}
\hline Mean Score & Classification \\
\hline $66-75$ & Fairly Good \\
\hline
\end{tabular}


From the data above, it is known that mean score is 75.86 . It meansthat studentse achievement of the eighth grade students of MTs Negeri 1 Makassar is in the fairly good classification.

2. The Relationship of Parental Involvement and Students"e Success

Based on the data from the parental involvement in the studentse success, the researcher counted the correlation between the aspects. The last islooking for the coefficient correlation between parental involvement with thestudents ${ }^{\text {ee }}$ success (students ${ }^{\text {ee }}$ English learning achievement) by PearsonProduct Moment formula in SPSS. The data can be seen in

Table 6. The Correlation Between Parental Involvement and Students' English Achievement

\begin{tabular}{|c|c|c|}
\hline \multicolumn{3}{|c|}{ Correlations } \\
\hline & Questionnaire & EnglishAchievement \\
\hline $\begin{array}{l}\text { QuestionnairePearson Correlation } \\
\text { Sig. (2-tailed) }\end{array}$ & 1 & $\begin{array}{l}.125 \\
.432\end{array}$ \\
\hline $\mathrm{N}$ & 42 & 42 \\
\hline $\begin{array}{l}\text { EnglishAchievPearson Correlation } \\
\text { ement } \\
\end{array}$ & $\begin{array}{l}.125 \\
.432 \\
42\end{array}$ & $\begin{array}{c}1 \\
42\end{array}$ \\
\hline
\end{tabular}

After counting the formula, the writer found out the result of thecorrelation. The next

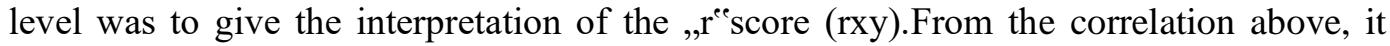
appears that the correlation index between Xvariable and $\mathrm{Y}$ variable is positive. It means between both variables, there ispositive correlation. To give simple interpretation toward the correlation index, re product moment (rxy), it can be seen in Table 7.

Table 7. Index Correlation ( $r$ )

\begin{tabular}{|c|c|}
\hline Coefficient Correlation & Level of Correlation \\
\hline $0.000-0.199$ & Very Weak \\
\hline
\end{tabular}

Based on the calculation above, the researcher concludes that thecorrelation between variable $\mathrm{X}$ and variable $\mathrm{Y}$ has the positive correlationwith the score of correlation 0.125 (it is categorized "very weakcorrelation").

\section{DISCUSSION}

On this section, the researcher discusses about the result of theresearch, namely parental involvement in students"e success, and the relationshipof parental involvement and students"e success.

\section{Parental Involvement in Students ${ }^{\text {ee Success }}$}

Parental involvement is shown by the scores based on the parentseanswers toward the questionnaire. The students ${ }^{\text {ee }}$ success is shown by thestudentsee English achievement got from the values given by the teacher fromthe students" final test at odd semester in 2015. 
Parental involvement $(\mathrm{X})$ is shown through the mean score got bythe parents, that is 16.19. It was taken from the Mean Score of ParentalInvolvement related to parenting (3.20), communicating (2.76), volunteering(2.43), learning at home (2.49), decision making (2.78), collaborating withcommunity (2.53).

The students"e English achievement was taken from the Mean Scoresof Studentse values in doing their final semester tests. The intensity of parental involvement that is $12.29 \%$ is categorizedas the highest involvement. The next is $11.88 \%$ is categorized as high, $10.87 \%$ is categorized average, and $6.96 \%$ is categorized low. The mean score ofthe role of parents at the eighth grade students of MTsN 1 Makassar in Academic Year of $2018 / 2019$ is low, and is categorizedas fairly good.

\section{The Relationship of Parental Involvement and Students ${ }^{\text {ee Success }}$}

The relationship between parental involvement and students ${ }^{\text {ee }}$ successis counted using SPSS. The scores counted are the score of parental roles andthe studentse achievement.The relationship between $\mathrm{X}$ and $\mathrm{Y}$ is shown by the score ofcoefficient correlation that is $r=0.125$. It means that there is positiverelationship between parental involvement $(\mathrm{X})$ and students ${ }^{\text {ee }}$ Englishachievement $(\mathrm{Y})$ at theeighth grade students of MTsN 1 Makassar in Academic Year of 2018/2019, but the relationship is very weak.

There were some reasons parental involvement has very weakrelationship on students ${ }^{\text {ee }}$ English achievement:

Parents are only focusing in providing their children with instrumentalneeds such as providing enough money, uniforms, and health. Parents are lessfocusing in developing their knowledge in educating their children.Most parents tended to follow the meeting with school but they do notcommunicate with school to talk about the studentse achievement, not knowtheir children problems whether their children were or not at school.Parents are only focusing in supporting school program, such asEnglish contest and provide the capital of the school, but parents are less inproviding ideas, and active in supporting at school.Parents are only focusing in preparing an English book for theirchildren. Parents are less in helping and monitoring the children in learning athome.

Parents are less collaborated with other parents and social organization to increase the quality of education, especially in English education.Parents are not collaborated with other parents and society to increasetheir children "english achievement to develop English program at school.Although parental involvement had positive relationship to thestudents ${ }^{\text {ee }}$ English learning achievement, in fact the result of the analysisshowed that parents who involve in their children "s education cannot reach themaximum level that is 1.000. It indicated that the relationship betweenparental involvement and studentse English achievement was in very weakcorrelation. It means that the studentse English achievement in eighth grade students of MTsN 1 Makassar in Academic Year of 2018/2019 was still being affected by other factorswhich were not studied now.

\section{CONCLUSIONS}

The student parental involvement of the eighth grade students of MTs Negeri 1 Makassar isshown by the mean score that is 16.19. This is categorized as low. Thestudentse English achievement is shown by the mean score that is 75.86. Thisis categorized as fairly good. Therefore, the relationship between parental involvement and studentachievement is categorized as very weak. This is proved by the value of $r$ thatis 0.125 . This coefficient 
correlation explains that there is a positivecorrelation between parental involvement and students $^{\text {ee }}$ achievement but the relationship is very weak. Based on the result of the research, the researcher gives suggestions. Thy are parents should encourage their children "s academic,because it can support the children"s academic success and parents should realize that they are first educators who provides educationalmilieu for their children.

\section{REFERENCES}

ACT. (2007). Issues In Collage Success: Impact of Cognitive, Psychosocial, and Career Factors on Educational and Workplace Success. (https://www.act.org/research/policymakers/pdf/CognitiveNoncognitive.pdf, RetrievedAugust $26^{\text {th, }}, 2018$ ).

Catsambis. (2001). Parents' Relationships and Involvement. Online. (http://files.eric.ed.gov/fulltext/EJ801108.pdf, Retrieved December, 5 2018).

Davis-Kean, P., \& Sexton, H.. (2009). Race Differences in Parental Influences on Child Achievement: Multiple Pathways to Success. Merrill - Palmer Quarterly, 55(3), 285-318. Retrieved October 26 ${ }^{\text {th }}$, 2018, from ProQuest Psychology Journals.

Depdikbud. (1986). Pedoman Penulisan Laporan Penelitian. Jakarta. Usaha Nasional.

Desforges, et al. (2003). The Impact of Parental Involvement, Parental Support, and Family Education on Pupil Achievement and Adjustment. Journal. (www.bgfl.org/bgfl/custom/files_uploaded/uploaded.../Desforges.pdf, Retrieved September $\left.9^{\text {th }}, 2018\right)$.

Edmonds and Walberg. (1995). In Search of the Elusive Magic Bullet: Parent Involvement and Student Outcomes. Journal, Vol. 5, No. 2. (http://eric.ed.gov/\%3Fid\%3DED381228, Retrieved December, $5^{\text {th }}, 2018$ ).

Epstein. (1997). Epstein Six Types of Involvement. (Online). (http://www.csos.jhu.edu/p2000/sixtypes.htm, Retrieved December, $5^{\text {th }}$ 2018).

Karsidi. et al. (2013). Parental Involvement on School Committees Social Capital to Improve Student Achievement. Journal. http://ehe.pitt.edu/ojs/index. Php/ehe/article/view/81RetrievedDecember $21^{\text {th }} 2018$.

Kunar. (2012). Parental Involvement in Schools. Journal. (http://www.childtrends.org/\%3Findicators\%3Dparental-involvementinschools, Retrieved December $\left.5^{\text {th }}, 2018\right)$.

Lawson, M, et al. (2012). Understanding Parental Involvement in American Public Education.Journal.(http://www.ijhssnet.com/journals/Vol_2_No_19_Special_Issue _October_20 12/4.pdf, Retrieved December $5^{\text {th }}, 2018$ ). 
Pomerants, Moorman, and Litwack. (2007). Parents' Involvement in Their Children's

Education.

(Online).

https://aifs.gov.au/sites/default/files/bw.pdfRetrievedDecember, $21^{\text {th }} 2018$ ).

Richards, E. J. (2004). Cambridge Encyclopedia: Attention. Journal. (https://www.google.com/search?q=defenition++about+Attention+menurut+p ara + ahli\&ie $=$ utf $-8 \& o e=$ utf $-8 \# q=$ definition + of + Attention + pdf , Retrieved September $9_{\mathrm{th}}, 2018$.

Sudjono, A. (2014). Pengantar Statistik Pendidikan. PT Rajawali Pers: Jakarta. 